\title{
Intestinal Parasites of Free-ranging, Semicaptive, and Captive Pongo abelii in Sumatra, Indonesia
}

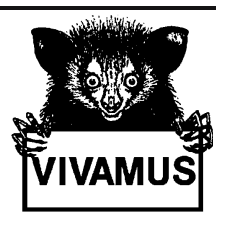

\author{
Irene F. Mul • Wardy Paembonan • Ian Singleton • \\ Serge A. Wich • Hester G. van Bolhuis
}

Received: 28 September 2005 / Revised: 30 January 2006 / Accepted: 6 March 2006 /

Published online: 2 May 2007

(C) Springer Science + Business Media, LLC 2007

\begin{abstract}
We collected fecal samples from 32 free-ranging, 19 semicaptive, and 54 captive Sumatran orangutans on Sumatra from 1998 until 2004 and screened them for gastrointestinal parasites. Our objectives were to compare the intestinal parasites of free-ranging, semicaptive, and captive orangutans and to evaluate the risk of parasite transmission in orangutan reintroduction programs. We identified 4 genera of Protozoa, 7 genera of nematodes, 1 trematode sp., and 1 cestode sp. The prevalence of Balantidium coli in free-ranging orangutans was significantly higher than in captive individuals. However, the prevalence of Strongyloides sp. was higher in captive than in free-ranging orangutans. Free-ranging female orangutans had a significantly higher total prevalence of intestinal parasites than that of males. We found no significant difference between parasite prevalences in different age groups. Compared to gorillas and chimpanzees, orangutans carry a smaller variety of protozoan and nematode species. Strongyloides sp. infections form the highest risk in reintroduction programs as crowding, ground-dwelling, and poor hygiene in captive and semicaptive orangutans may cause a constant reinfection.
\end{abstract}

Keywords intestinal parasites $\cdot$ great ape $\cdot$ Pongo abelii $\cdot$ reintroduction $\cdot$ Sumatran orangutan

\footnotetext{
I. F. Mul (ه)

Department of Veterinary Pathobiology, Utrecht University, Faculty of Veterinary Medicine, W.v. Abcoudelaan 19, 3971 AA Oriebergen, The Netherlands e-mail: mulirene@hotmail.com

W. Paembonan · I. Singleton

Sumatran Orangutan Conservation Programme, Jl. K.H. Wahid Hasyim No 51, Medan Baru, Medan 20154 North Sumatra, Indonesia

\section{S. A. Wich}

Great Ape Trust of Iowa, 4200 Se 44th Ave., Des Moines, IA 50320, USA

H. G. van Bolhuis

AAP Foundation, PO Box 50313, 1305 AH Almere, The Netherlands
} 


\section{Introduction}

Orangutans (Pongo spp.) are the only great ape species to inhabit Southeast Asia. At present, their distribution is restricted to Sumatra and Borneo in Indonesia, and the Malaysian states of Sabah and Sarawak. Unfortunately their numbers in the wild are decreasing rapidly. In 1997 the orangutan population estimate for Bornean orangutans (Pongo pygmaeus) was only $7 \%$ of the population in 1900. The estimated Sumatran population in 2002 was 4\% of the population in 1900 (Rijksen and Meijaard 1999; Wich et al. 2003). On the IUCN Red List Sumatran orangutan (Pongo abelii) are critically endangered (IUCN 2004). The main threats to their survival are hunting, trade, and habitat loss (Rijksen 1974; Rijksen and Meijaard 1999; Robertson and van Schaik 2001; Singleton et al. 2004).

To enhance the survival of free-ranging orangutans in Indonesia, reintroduction programs were started on Borneo in the mid-1960s and on Sumatra in the early 1970s to release wild-caught, captive orangutans back into the wild. In the past, researchers reintroduced orangutans into the forest that free-ranging orangutan populations still inhabited. The Indonesian Ministry of Forestry effectively terminated the rehabilitation role of all centers that release animals into existing wild populations in its newest Ministerial Guidelines for Rehabilitation (Keputusan Menteri Kehutanan No. 280/kpts-II/1995), which state that every effort should be made to find suitable areas with no existing wild populations for all rehabilitation projects. Reintroduction is allowed only into areas that are within the historic specific range but without remnant wild individuals to prevent disease spread, social disruption, and introduction of alien genes (IUCN 2004).

Orangutans are susceptible to most human pathogenic organisms, and transmission of parasitic infections has occurred (Chitwood 1970; Hegner 1928; Orihel 1970; OttJoslin 1993). Important sources of parasite exposure to captive, semicaptive, and freeranging great apes are tourists, researchers, guides, rangers, animal keepers, and unintentional human contact such as villagers, poachers, and loggers (Woodford et al. 2002). Reintroduced orangutans, carrying parasititic infections, may introduce uncommon parasite species in naïve free-ranging primate populations, including orangutans. In addition, captive orangutans could be exposed to parasites common in free-ranging primate populations. In both cases, alien parasitic infections may cause serious illness or even death in a naïve host. Most intestinal parasites are commensals, but because of stress, pregnancy, bad condition, old age, or disease, defense mechanisms could fail and the parasitic infection may cause sickness or death (Collet et al. 1986; Cummings et al. 1973; Harper et al. 1982; Jaskoski 1960; McClure et al. 1973; Patten 1939; Rijksen 1978; Uemera et al. 1979; Warren 2001).

Researchers have investigated intestinal parasites of free-ranging, semicaptive, and captive orangutans. Several authors examined free-ranging and semicaptive orangutans in Sumatra, Borneo and Malaysia (Collet et al. 1986; Djojosudharmo and Gibson 1993; Djojoasmoro and Purnomo 1998; Kilbourn et al. 2003; Rijksen 1978; Warren 2001; Frazier-Taylor et al. 1984, unpublished; Moresco-Pimentel, unpublished). We obtained captive orangutan data from zoos in the United States (Cummings et al. 1973), in Java, Indonesia (Collet et al. 1986), Spain (Gómez et al. 1996), and Borneo, Indonesia (Djojoasmoro and Purnomo 1998; Warren 2001). The results of the studies in Table I. Rijksen (1978), Collet et al. (1986), Djojosudharmo 
and Gibson (1993), and Moresco-Pimentel (unpublished) were the only authors who studied free-ranging and semicaptive Sumatran orangutans. To our knowledge, researchers have never reported endoparasitic infections in captive Sumatran orangutans before.

There are numerous reports on the intestinal parasites of the other great apes: Gorilla spp. (Ashford et al. 1990, 1996; Durette-Desset et al. 1992; Freeman et al. 2004; Hastings et al. 1992; Kalema 1995; Kalema-Zikusoka et al. 2002; LandsoudSoukate et al. 1995; Lilly et al. 2002; Mudakikwa et al. 1998, 2001; Nizeyi et al. 1999; Rothman et al. 2002; Sleeman et al. 2000; van Waerebeke et al. 1988) and Pan spp. (Ashford et al. 2000; File et al. 1976; Hasegawa et al. 1983; Holmes 1980; Huffman et al. 1997; Hugot 1993; Kawabata and Nishida 1991; Kim et al. 1978; Landsoud-Soukate et al. 1995; Lilly et al. 2002; McGrew et al. 1989; Murray et al. 2000; Schmidt and Prine 1970; Smith et al. 1996; van Waerebeke et al. 1988; Wrangham 1995).

We surveyed fecal parasites from 3 groups of Sumatran orangutans, with 2 objectives: First, we compared the overall prevalence of intestinal parasites in

Table I Intestinal parasites in fecal samples of captive, semicaptive, and free-ranging orangutans reported in previous studies

\begin{tabular}{|c|c|c|c|}
\hline & Captive orangutans & Semicaptive orangutans & Free-ranging orangutans \\
\hline \multicolumn{4}{|l|}{ Protozoa } \\
\hline Entamoeba $\mathrm{sp}$. & 4,6 & 3,4 & 3,4 \\
\hline Entamoeba histolytica & 4 & 4 & 4 \\
\hline E. chattoni & 6 & & \\
\hline Iodamoeba butschlii & 6 & & \\
\hline Blastocystis hominis & 6 & & \\
\hline Balantidium coli & $1,4,6,8$ & $4,8,9$ & $2,4,5,8,9$ \\
\hline Cyclospora sp. & 8 & & \\
\hline Giardia lamblia & 1 & & \\
\hline Enteromonas hominis & 6 & & \\
\hline \multicolumn{4}{|l|}{ Nematodes } \\
\hline Strongyloides sp. & $1,4,7,8$ & $3,4,7,8,9$ & $2,3,4,5,7,8,9$ \\
\hline Strongylida sp. & $1,4,8$ & $3,4,8$ & $3,4,5,8,10$ \\
\hline Mammoтопоgатus sp. & & 4 & \\
\hline Ancylostoma sp. & & 2 & 2 \\
\hline Ternidens sp. & & & 5 \\
\hline Oesophagostomum sp. & 7 & 7 & 2,7 \\
\hline Trichostrongylus sp. & & & 2,7 \\
\hline Pithecostrongylus alatus & & & 2 \\
\hline Abbreviata caucasica & & & 2 \\
\hline Enterobius sp. & 1 & $4,7,9$ & $2,5,7,10$ \\
\hline Ascaris sp. & $1,4,7,8$ & 2,4 & 5 \\
\hline Trichuris sp. & $1,7,8$ & $2,3,4,8,9$ & $2,3,4,7,9,10$ \\
\hline \multicolumn{4}{|l|}{ Trematodes } \\
\hline Dicrocoeliidae sp. & 4 & 4 & 4,5 \\
\hline Gasterodiscoides sp. & & & 2 \\
\hline Cestodes & 1 & & \\
\hline Bertiella sp. & & 4 & \\
\hline
\end{tabular}

1, Cummings et al. (1973); 2, Rijksen (1978); 3, Frazier-Taylor et al. (1984, unpublished); 4, Collet et al. (1986); 5, Djojosudharmo and Gibson (1993); 6, Gómez et al. (1996); 7, Djojoasmoro and Purnomo (1998), 8, Warren (2001); 9, Kilbourn et al. (2003); 10, Moresco-Pimentel (unpublished). 


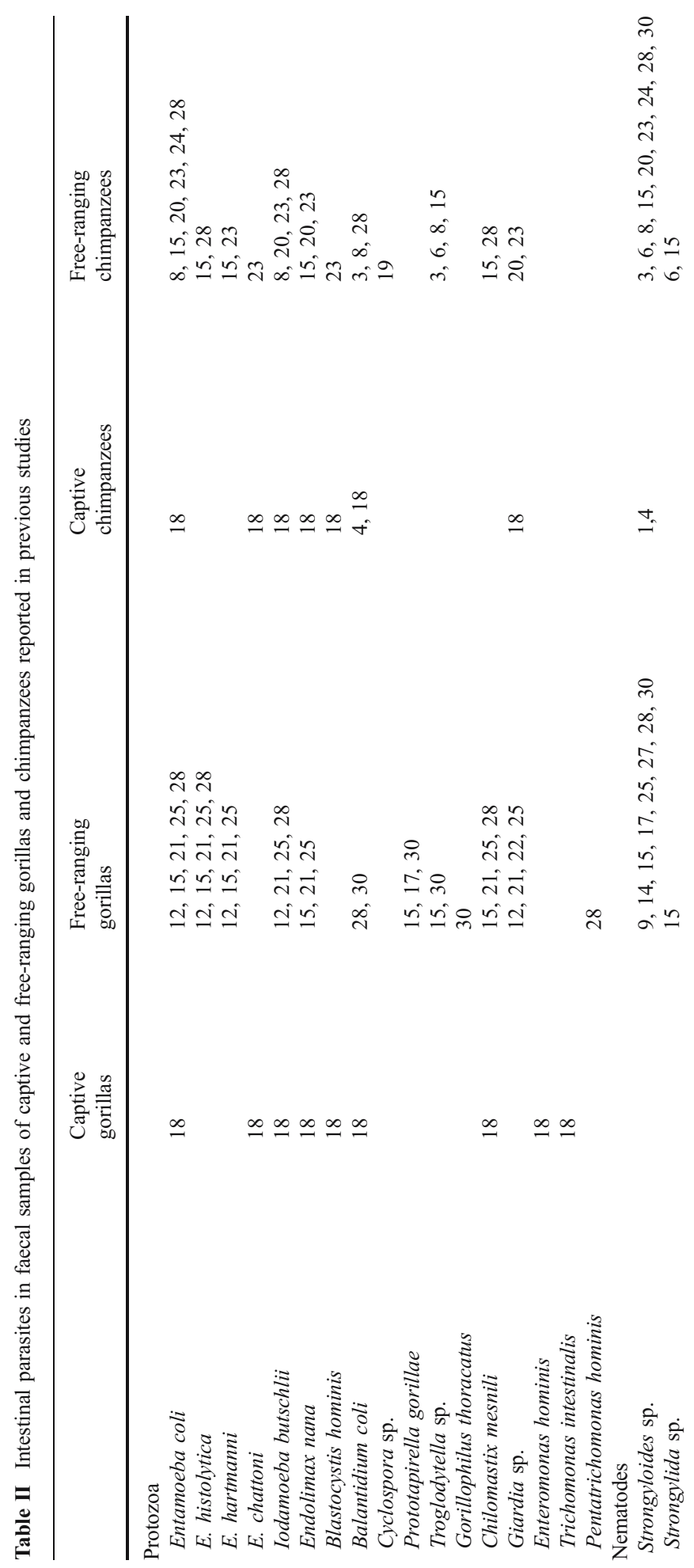




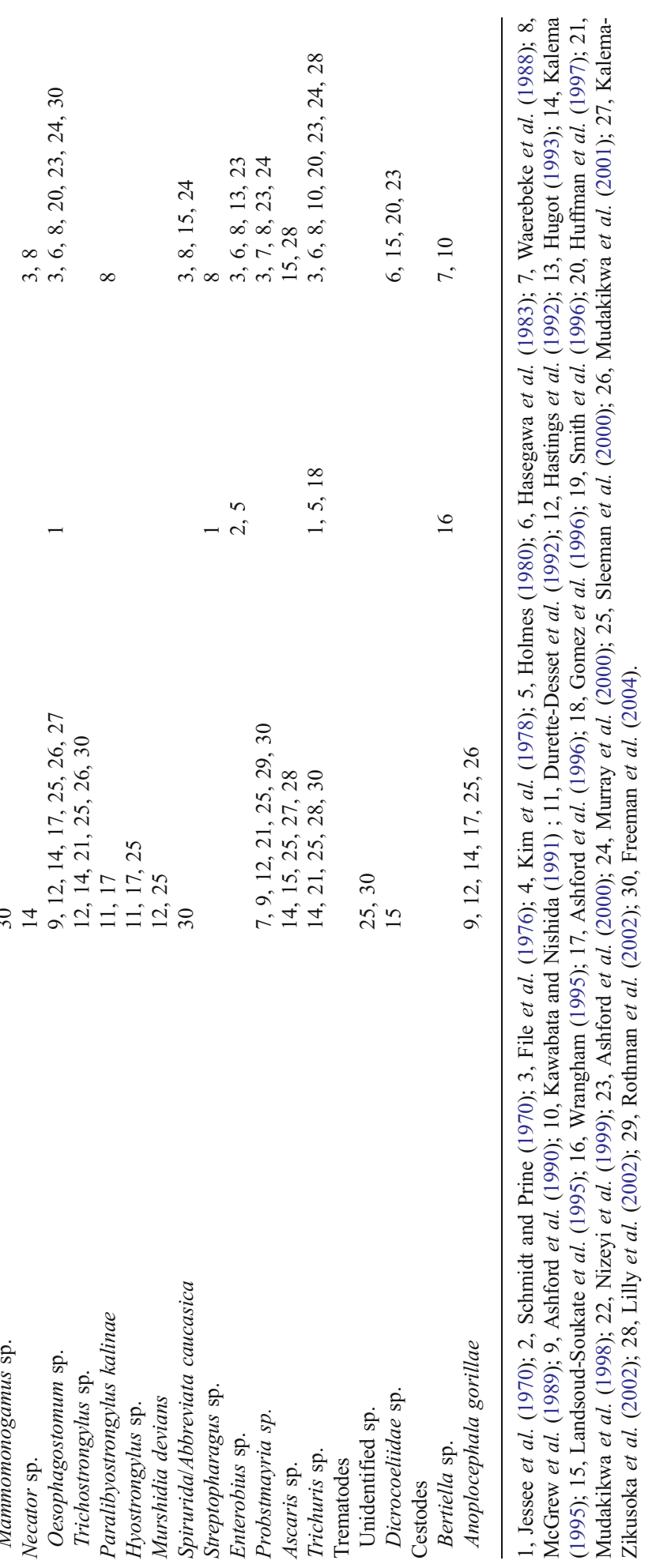


free-ranging, semicaptive, and captive Sumatran orangutans of different sexes and ages and to compare the parasite species between the 3 groups. In addition, we compared the results of previous studies on the intestinal parasites of other great apes (Gorilla spp. and Pan spp.) in Africa (Table II). Second, we evaluated the risk of parasite transmission in orangutan-reintroduction programs.

\section{Materials and Methods}

Subjects

We studied the quarantine of the Sumatran Orangutan Conservation Program (SOCP) in North Sumatra, Indonesia. We collected samples from free-ranging (wild), semicaptive (wild-caught orangutans that are released into the wild after a reintroduction program), and captive (orangutans in zoos and reintroduction programs) Sumatran orangutans from 5 different locations. Captive orangutans lived at Medan Zoo in Medan, North Sumatra $\left(3^{\circ} 35^{\prime} \mathrm{N}, 98^{\circ} 41^{\prime} \mathrm{E}\right)$ and at the SOCP quarantine in Batu Mbelin, North Sumatra. Semicaptive orangutans lived at the reintroduction site of the SOCP in Jambi, Central Sumatra $\left(1^{\circ} 9^{\prime} \mathrm{S}, 102^{\circ} 33^{\prime} \mathrm{E}\right)$ and at the former rehabilitation site Bohorok, North Sumatra $\left(3^{\circ} 30^{\prime} \mathrm{N}, 98^{\circ} 12^{\prime} \mathrm{E}\right)$, which closed for rehabilitation in 1996 . We followed freeranging orangutans at the Ketambe research station $\left(3^{\circ} 41^{\prime} \mathrm{N}, 97^{\circ} 39^{\prime} \mathrm{E}\right)$ in the Gunung Leuser National Park, Leuser Ecosystem in North Sumatra.

The reintroduction site in Jambi has an area of $1200 \mathrm{~km}^{2}$ and does not currently contain a resident wild orangutan population. The last report of the presence of a (dead) orangutan in Jambi was roughly 165 yr ago by Schlegel and Müller (18391844). At the time of our study, $c a$. 20 orangutans had already been released into this National Park. Both Bohorok and the Ketambe Research Station, are located in the Leuser Ecosystem in Northern Sumatra. The Leuser Ecosystem covers ca. 25,000 km² and encompasses the designated Gunung Leuser National Park covering $c a .9000 \mathrm{~km}^{2}$ (van Schaik et al. 2001). In 2004 ca. 7300 orangutans remained in the wild in Northern Sumatra (Singleton et al. 2004).

\section{Sample Collection and Analysis}

We collected fecal samples from free-ranging, semicaptive, and captive Sumatran orangutans in 1998 and from 2002 until 2004. Based on data from Kilbourn et al. (2003), Rijksen (1978), and Moresco-Pimentel (unpublished), we considered orangutans $\leq 8 \mathrm{yr}$ as young and orangutans $>8 \mathrm{yr}$ as adult. Of each freshly passed fecal specimen we mixed 1 part feces with 3 parts of SAF fixative (sodium acetateacetic acid-formaldehyde) directly after collection. We concentrated the samples via the Ridley method with ethyl acetate instead of ether (Polderman and Rijpstra 1993), using the Faecal Parasite Concentrator kit (FPC ${ }^{\circledR}$, Evergreen Scientific, International Medical Products BV, Zutphen, the Netherlands).

We scanned the sediments via light microscopy for protozoan cysts, helminth eggs, and larvae at $\times 10$ objective power and conducted detailed examination at $\times 45$ objective power. We identified the cysts and helminth ova with the assistance of 
published keys (Arcari et al. 2000; Bowman et al. 1999; Collet et al. 1986; Jessee et al. 1970; Polderman and Rijpstra 1993; Thienpont et al. 1979). We stored unidentified eggs and identified them later in consultation with other experts.

\section{Statistical Analysis}

We used nonparametric tests for statistical analysis, as the data were not normally distributed. We compared the total prevalence of intestinal parasites from captive, semicaptive, and free-ranging orangutans with the Friedman test and the KruskalWallis test. We tested the individual prevalence of all parasites with the $\chi^{2}$ test, to determine if there were significant differences between captive, semicaptive, and free-ranging orangutans. We compared data from young and adult and male and female orangutans via the Wilcoxon signed ranks test.

\section{Results}

We examined fecal samples of 105 individuals - 54 captive, 19 semicaptive, and 32 free-ranging - for parasite cysts, eggs, and larvae. The 105 orangutans comprised 50 males and 55 females. We considered 52 individuals as young and 51 as adult orangutans, but did not know the ages of 2 orangutans. We took multiple fecal samples per orangutan; the results per individual are in Table III.

All but 6 orangutans tested positive for $\geq 2$ different intestinal parasites. We found cysts of 4 species of Protozoa, eggs of 7 different nematode species, 1 trematode species (measuring $42.5 \times 25 \mu \mathrm{m}$, brown, thick-shelled, smooth surface, operculum), and 1 unknown cestode species (measuring $44 \times 30 \mu \mathrm{m}$, brown, thin shell, smooth surface, oncosphere; Table III). Entamoeba sp. (range 7.5-37.5 - 7.5-37.5 $\mu \mathrm{m}$, spherical, 18 nuclei), Balantidium coli (range 30-50×27.5-50 $\mu \mathrm{m}$, spherical brown cysts and brown trophozoites containing cilia), Strongyloides sp. (range 45-57.5×25-37.5 $\mu \mathrm{m}$, oval, smooth thin shell, morula) and species of Strongylida (range 62.5-75 $\times 32.5-$ $50 \mu \mathrm{m}$, oval, smooth thin shell, morula) were the most common intestinal parasites, irrespective of whether orangutans were free-ranging, semicaptive, or captive (Table III). We found Chilomastix sp. (range 6-10×5-8 $\mu \mathrm{m}$, lemon shaped, large nucleus) and eggs of Spirurida (47.5-55 $\times 22.5-32.5 \mu \mathrm{m}$, dark brown, thick-shelled, irregular surface, morula) in fecal samples of captive and free-ranging orangutans. We discovered eggs of Mammomonogamus sp. (range 67.5-77.5 $\times 40-42.5 \mu \mathrm{m}$, oval, thick shell, morula), Enterobius sp. (range 52-56 $\times 25-30 \mu \mathrm{m}$, oval, thin shell, asymmetrical shape, contain larva) and Trichuris sp. (range 50-52.5 $\times 20-25 \mu \mathrm{m}$, barrel shaped, bipolar plugs, thick shell) in free-ranging, semicaptive, and captive orangutans. Giardia sp. (measuring $10 \times 6 \mu \mathrm{m}$, ellipsoid) and Ascaris sp. (range 45$52 \times 35-38 \mu \mathrm{m}$, oval, brown, thick wall, irregular surface) were present only in fecal samples of captive orangutans.

There is no significant difference for the overall prevalence of intestinal parasites among captive, semicaptive, and free-ranging individuals. Significant differences in prevalence occur only for Balantidium coli $\left(\chi^{2}=26.8, p<.01\right)$, which is higher in free-ranging than in captive orangutans (Table III) and Strongyloides sp., 
which is significantly higher in captive than in free-ranging orangutans $\left(\chi^{2}=11.2\right.$, $p<.05)$. There is a significant difference between free-ranging males and females; females had a higher overall prevalence of intestinal parasites than males (Wilcoxon, $N=17, p=.008)$. There is no significant difference between young and adult orangutans.

\section{Discussion}

We investigated whether there are variations in the overall prevalence of intestinal parasites and whether or not there are differences in parasite species between captive, semicaptive, and free-ranging orangutans. We found no significant differences for the overall prevalence of intestinal parasites and no great differences in the parasite species between captive, semicaptive, and free-ranging orangutans. Except for Chilomastix sp., Giardia sp., Spirurida sp., Ascaris sp., Dicrocoeliidae sp., and a cestode sp., all parasites were present in fecal samples, irrespective of whether orangutans were free-ranging, semicaptive, or captive (Table III).

To our knowledge, there is no previous report on intestinal parasites in captive Sumatran orangutans. Compared to data from captive Bornean orangutans (Collet et al. 1986; Djojoasmoro and Purnomo 1998; Warren 2001), this is the first report of Chilomastix sp., Giardia sp., Mammomonogamus sp., Enterobius sp., a spirurid species, and a cestode species in captive orangutans. Collet et al. (1986) reported the presence of trematode eggs of the Dicrocoeliidae in captive orangutans in Surabaya

Table III Number of parasitic infections detected on fecal examination of 54 captive, 19 semicaptive, and 32 free-ranging male and female Sumatran orangutans

\begin{tabular}{|c|c|c|c|c|c|c|c|c|c|}
\hline & \multicolumn{3}{|c|}{ Captive orangutans } & \multicolumn{3}{|c|}{ Semicaptive orangutans } & \multicolumn{3}{|c|}{ Free-ranging orangutans } \\
\hline & $\begin{array}{l}\text { Total } \\
(n=54)\end{array}$ & $\begin{array}{l}\text { Male } \\
(n=31)\end{array}$ & $\begin{array}{l}\text { Female } \\
(n=23)\end{array}$ & $\begin{array}{l}\text { Total } \\
(n=19)\end{array}$ & $\begin{array}{l}\text { Male } \\
(n=6)\end{array}$ & $\begin{array}{l}\text { Female } \\
(n=13)\end{array}$ & $\begin{array}{l}\text { Total } \\
(n=32)\end{array}$ & $\begin{array}{l}\text { Male } \\
(n=13)\end{array}$ & $\begin{array}{l}\text { Female } \\
(n=19)\end{array}$ \\
\hline \multicolumn{10}{|l|}{ Protozoa } \\
\hline Entamoeba sp. & 47 & 27 & 20 & 11 & 4 & 7 & 22 & 6 & 16 \\
\hline Balantidium coli & 10 & 5 & 5 & 7 & 2 & 5 & 24 & 9 & 15 \\
\hline Giardia sp. & 1 & 1 & 0 & 0 & 0 & 0 & 0 & 0 & 0 \\
\hline Chilomastix sp. & 10 & 8 & 2 & 0 & 0 & 0 & 4 & 0 & 4 \\
\hline \multicolumn{10}{|l|}{ Nematoda } \\
\hline Strongyloides sp. & 44 & 24 & 20 & 9 & 2 & 7 & 15 & 6 & 9 \\
\hline Strongylida sp. & 18 & 9 & 9 & 5 & 0 & 5 & 12 & 5 & 7 \\
\hline $\begin{array}{l}\text { Mammomonogamus } \\
\text { sp. }\end{array}$ & 5 & 3 & 2 & 4 & 1 & 3 & 6 & 1 & 5 \\
\hline Spirurida sp. & 1 & 1 & 0 & 0 & 0 & 0 & 3 & 1 & 2 \\
\hline Enterobius sp. & 3 & 3 & 0 & 1 & 0 & 1 & 1 & 0 & 1 \\
\hline Ascaris sp. & 6 & 3 & 3 & 0 & 0 & 0 & 0 & 0 & 0 \\
\hline Trichuris sp. & 16 & 10 & 6 & 2 & 1 & 1 & 6 & 2 & 4 \\
\hline Larva indefinable & 7 & 6 & 1 & 1 & 1 & 0 & 6 & 2 & 4 \\
\hline \multicolumn{10}{|l|}{ Trematoda } \\
\hline Dicrocoeliidae sp. & 0 & 0 & 0 & 1 & 0 & 1 & 0 & 0 & 0 \\
\hline Cestoda & 1 & 1 & 0 & 0 & 0 & 0 & 0 & 0 & 0 \\
\hline $\begin{array}{l}\text { Negative } \\
\text { examinations }\end{array}$ & 1 & 1 & 0 & 2 & 2 & 0 & 3 & 3 & 0 \\
\hline
\end{tabular}


Zoo in Java, Indonesia. Djojoasmoro and Purnomo (1998) reported the presence of Strongyloides fulleborni and Oesophagostomum sp. in Borneo. We did not identify the parasites in captive orangutans.

This is the first report of Chilomastix sp. and Mammomonogamus sp. in freeranging orangutans. Other parasites found in Sumatran free-ranging orangutans corresponded to previous studies (Collet et al. 1986; Djojosudharmo and Gibson 1993; Rijksen 1978; Moresco-Pimentel, unpublished), with the exception of some parasites not found in our subjects: Djojosudharmo and Gibson (1993) reported the presence of eggs of Ascaris sp. and trematodes and Rijksen (1978) identified the trematode Gasterodiscoides sp., the strongylid Oesophagostomum blanchardi, the trichostrongylids Pithecostrongylus alatus and Trichostrongylus colubriformis, and the spirurid Abbreviata caucasica in free-ranging Sumatran orangutans (Table I). It was impossible to identify the eggs of the Strongylida and Spirurida to specific level via the techniques we used. We detected trematode eggs of the Dicrocoeliidae for the first time in semicaptive orangutans. Rijksen (1978) and Collet et al. (1986) reported the presence of Ascaris sp. in semicaptive orangutans and Collet et al. (1986) also reported the presence of Bertiella sp. in semicaptive orangutans; we found neither.

We found eggs of Mammomonogamus sp. in the semicaptive orangutans at Bohorok, similar to the findings of Collet et al. (1986), but we also found eggs of the species in feces of free-ranging and captive orangutans. The parasite may be transmitted to free-ranging individuals by other primate species, which live in overlapping areas. Mammomonogamus sp. can also infect humans, who might have transmitted the parasite to the orangutans in the zoo in Medan. Collet et al. (1986) reported Mammomonogamus sp. for the first time in Sumatran orangutans. Mammomonogamus sp. is a nematode parasite that inhabits the respiratory tract. In 1980, 5 young orangutans died after symptoms of dyspnea and listlessness caused by the parasite. In some circumstances, the parasite is easily transmissible and a definite health hazard to orangutans (Collet et al. 1986).

We found a significant difference among the 3 groups of orangutans with regard to Balantidium coli, which had a significantly higher prevalence in free-ranging than in captive orangutans. The prevalence of Strongyloides sp. was higher in captive than in free-ranging orangutans. Balantidium coli is a ciliate in the cecum and colon of pigs (Bowman et al. 1999; Hegner 1928; Lee et al. 1990; Levine 1970; Nelson 1934). Wild pigs in Sumatra share their habitat with orangutans (Rijksen 1978). The feces of wild pigs may contaminate the food and water of orangutans when they share the same habitat, which may explain the high prevalence of Balantidium coli in free-ranging orangutans in our sample. Strongyloides sp. can live primarily in humans or nonhuman primates depending on the subspecies (Bowman et al. 1999; Hegner 1928; Hira and Patel 1980; Kelly et al. 1976). In our study the prevalence of Strongyloides sp. was higher in captive than in free-ranging orangutans. The Strongyloides sp. we found could be $S$. stercoralis, which is transmitted by human contact, but without culture, it was not possible to identify to specific level. Crowding, ground dwelling, and bad hygiene, which may occur in populations of captive and semicaptive orangutans, can cause a constant reinfection with Strongyloides stercoralis. When the cell-mediated immunity is suppressed, as in the case with young or sick individuals, the disease may become fatal (Cummings et al. 1973; Harper et al. 1982; McClure et al. 1973; Uemura et al. 1979; Warren 2001). 
One should administer a good anthelmintic medication such as ivermectin or mebendazole (Datry et al. 1994; Leeflang and Markham 1986; Warren 2001) to infected individuals. We found only Giardia sp. and Ascaris sp. in the captive orangutans. Both parasites are primarily parasites of humans (Bowman et al. 1999; Chitwood 1970; Landsoud-Soukate et al. 1995; Orihel 1970; Ott-Joslin 1993; Pawlowski 1982; Polderman and Rijpstra 1993) and were probably transmitted to orangutans at a time when they were living in close proximity to humans.

We found only negative parasitic results in males. Free-ranging female orangutans had a significantly higher total prevalence of intestinal parasites than males did, possibly because of the degree of physical contact with other orangutans. Females are accompanied by an infant for most of their lives and they travel relatively often with other females and their offspring. Adult females do not come in contact with each other a great deal, but while the females are feeding, the juveniles often play together; therefore a female effectively has second-hand contact with many other orangutans via her offspring.

Males achieve physical contact with other orangutans only during mating, rapes, or fights, which are rare occurrences (Singleton and van Schaik 2001; van Noordwijk and van Schaik 2005).

Many publications are available about the intestinal parasites of other great apes (Gorilla spp. and Pan spp.). Besides a few reports of endoparasites in captive great apes, almost all the reports provide data on the intestinal parasites of free-ranging great apes in African countries (Table II). All the parasites we found also occur in both gorillas and chimpanzees, with the exceptions of Enterobius sp. and cestode sp., which do not occur in gorillas, and Mammomonogamus sp., which do not occur in chimpanzees. In total there were more protozoan and nematode species in gorillas and chimpanzees than in orangutans, possibly because of differences in the techniques used and the conservation method of fecal samples. Another explanation could be the fact that gorillas and chimpanzees live together in groups and spend more time on the ground, in contrast to orangutans, which in general live solitarily in trees. Living on the ground may increase exposure to feces from both conspecifics and other species, and hence increase infection risk in chimpanzees and gorillas. Wich et al. (2004) have also argued that a lower risk of disease transmission is one of the possible explanations for the lower mortality of wild orangutans compared to chimpanzees. Dietary habits and differences in seasonal conditions may also cause the differences in parasite loads. Female chimpanzees normally have 2 or 3 offspring around them at 1 time, in contrast to orangutans, which carry only 1 offspring at a time, which could increase the chance of transmission of parasites (van Noordwijk and van Schaik 2005).

Of all the parasites we found, only some Entamoeba sp. and Chilomastix sp. are nonpathogenic (Bowman et al. 1999; Gómez et al. 1996; Hegner 1928; Levine 1970, 1973; Rijksen 1978). All the other parasites can become pathogenic when the host defense mechanism fails as a result of stress, pregnancy, poor physical condition, old age, or disease. Only a few of the orangutans in our study experienced diarrhea without any other symptom. We found no other symptom. There is no correlation between the presence of diarrhea and the parasite species in the individuals.

To decrease the risk of released orangutans introducing new parasites into freeranging naïve populations, one should not release captive orangutans into areas 算 Springer 
where free-ranging orangutans are living. Also, anthelmintic treatment of captive orangutans may decrease the transmission risk, though anthelmintic treatment never guarantees that the orangutan will be free of parasites. It is also not desirable to release orangutans that are totally free of parasites into the wild because they may be more susceptible to new infections from free-ranging nonhuman primate populations. To reduce the risk that the parasites cause sickness, one should release the captive individuals in optimal physical condition and avoid stress situations around their release as much as possible.

In conclusion, all 3 groups of orangutans had parasitic infections. All free-ranging female orangutans had a significantly higher total prevalence of intestinal parasites than those of males. Balantidium coli had a significantly higher prevalence in free-ranging than in captive orangutans, and Strongyloides sp. had a higher prevalence in captive than in free-ranging orangutans. Strongyloides sp. in particular is a high risk in reintroduction programs. Crowding, ground dwelling, and poor hygiene in captive and semicaptive orangutans cause a constant reinfection, which may become fatal if left untreated, especially in young individuals. To reduce the risk of reintroduction of Strongyloides sp. in free-ranging individuals, one should treat released orangutans with anthelmintics just before their release. However, it is not desirable to strive for the reintroduction of orangutans that are completely free of intestinal parasites, as infections with new parasites might become fatal in naïve hosts. Further research is required to identify the unknown species, e.g., Entamoeba sp., Strongyloides sp., Strongylida sp., and trematode and cestode species, down to the specific level and to evaluate better the health risks of parasite infections and parasite intensities in orangutans.

Acknowledgments We thank the Sumatran Orangutan Conservation Program, including staff of the PanEco Foundation, Frankfurt Zoological Society, and Yayasan Ekosistem Lestari in Indonesia for their support. We also thank all the field staff and other researchers at Ketambe, in Jambi and in Bohorok, along with the keepers and staff of SOCP's quarantine center and Medan Zoo for their assistance in collecting the samples. We thank the foundation Monkey Business in the Netherlands for donating an ocular micrometer. We acknowledge Drs. H. J. W. M. Cremers, who provided assistance with the parasite determination; Dr. G. M. Dorrestein, Department of Veterinary Pathobiology, Utrecht University, for supervising this study; and the Utrecht University in The Netherlands for financing this study. We acknowledge the cooperation and support of the Indonesian Institute of Science (LIPI, Jakarta) and the Indonesian Nature Conservation Service (PHKA) for permission to work in Indonesia. We also thank Universitas Nasional (Jakarta) for their support throughout the years. We thank the Netherlands Foundation for the Advancement of Tropical Research (WOTRO) and the Netherlands Organization for Scientific Research (NWO) for long-term financial support for the research at Ketambe.

\section{References}

Arcari, M., Baxendine, A., \& Bennett, C. E. (2000). Diagnosing Medical Parasites Through Coprological Techniques. Online book: http://www.soton.ac.uk/ ceb/Diagnosis/Voll.htm.

Ashford, R. W., Lawson, H., Butynski, T. M., \& Reid, G. D. F. (1996). Patterns of intestinal parasitism in the mountain gorilla, Gorilla gorilla, in the Bwindi-Impenetrable Forest, Uganda. Journal of Zoology, 239, 507-514.

Ashford, R. W., Reid, G. D. F., \& Butynski, T. M. (1990). The intestinal faunas of man and mountain gorillas in a shared habitat. Annals of Tropical Medicine and Parasitology, 84, 337-340.

Ashford, R. W., Reid, G. D. F., \& Wrangham, R. W. (2000). Intestinal parasites of the chimpanzee Pan troglodytes in Kibale Forest, Uganda. Annals of Tropical Medicine and Parasitology, 94, 173-179. 
Bowman, D. D., Lynn, R. C., \& Georgi, J. R. (1999). Georgis' parasitology for veterinarians (7th ed.). Philadelphia, London: W.B. Saunders Company.

Chitwood, M. (1970). Comparative relationships of some parasites of man and old and new world subhuman primates. Laboratory Animal Care, 20, 389-394.

Collet, J., Galdikas, B. M. F., Sugarjito, J., \& Jojosudharmo, S. (1986). A coprological study of parasitism in orangutans (Pongo pygmaeus) in Indonesia. Journal of Medical Primatology, 15, 121-129.

Cummings, L. B., Keeling, M. E., \& McClure, H. M. (1973). Preventive medicine in anthropoids: Parasite control. Laboratory Animal Science, 23, 819-822.

Datry, A., Hilmarsdottir, I., Mayorga-Sagastume, R., Lyagoubi, M., Gaxotte, P., Biligui, S., et al. (1994). Treatment of Strongyloides stercoralis infection with ivermectin compared with albendazole: Results of an open study of 60 cases. Transactions of the Royal Society of Tropical Medicine and Hygiene, 88, 344-345.

Djojosudharmo, S., \& Gibson, A. T. (1993). Parasit intestinalis pada primata liar di Taman Nasional Gunung Leuser, Sumatra. Presented for the Simposium \& Seminar Nasional Primata. Bandung, October 13-14.

Djojoasmoro, R., \& Purnomo, A. (1998). Prevalensi Nematoda Usus pada Orangutan di Taman Nasional Tanjung Puting Kalimantan Tengah. Journal of Primatology of Indonesia, 2, 9-12.

Durette-Desset, M., Chabaud, A. G., Ashford, R. W., Butynski, T. M., \& Reid, G. D. F. (1992). Two new species of the Trichostrongylidae (Nematoda: Trichostrongyloidea), parasitic in Gorilla gorilla beringei in Uganda. Systematic Parasitology, 23, 159-166.

File, S. K., McGrew, W. C., \& Tutin, C. E. G. (1976). The intestinal parasites of a community of feral chimpanzees, Pan troglodytess schweinfurthii. Journal of Parasitology, 62, 259-261.

Freeman, A. S., Kinsella, J. M., Cipolletta, C., Deem, S. L., \& Karesh, W. B. (2004). Endoparasites of Western Lowland Gorillas (Gorilla gorilla gorilla) at Bai Hokou Central African Republic. Journal of Wildlife Disease, 40, 775-781.

Gómez, M. S., Gracenea, M., Montoliu, I., Feliu, C., Monleon, A., Fernandez, J., et al. (1996). Intestinal parasitism-protozoa and helminths-in primates at the Barcelona Zoo. Journal of Medical Primatology, 25, 419-423.

Harper, J. S., Rice, J. M., London, W. T., Sly, D. L., \& Middleton, C. (1982). Disseminated Strongyloidiasis in Erythrocebus patas. American Journal of Primatology, 3, 89-98.

Hasegawa, H., Kano, T., \& Mulavwa, M. (1983). A parasitological survey on the feces of pygmy chimpanzees, Pan paniscus, at Wamba, Zaïre. Primates, 24, 419-423.

Hastings, B. E., Gibbons, L. M., \& Williams, J. E. (1992). Parasites of free-ranging mountain gorillas: Survey and epidemiological factors. In Proceedings of the Joint Meeting of the American Association of Zoo Veterinarians and the American Association of Wildlife Veterinarians, pp. 301-302.

Hegner, R. (1928). The evolutionary significance of the protozoan parasites of monkeys and man. Quarterly Review of Biology, 3, 225-244.

Hira, P. R., \& Patel, B. G. (1980). Human strongyloidiasis due to the primate species strongyloides fülleborni. Trophical and Geographical Medicine, 32, 23-29.

Holmes, D. D. (1980). Fatal enterobiasis in a Chimpanzee. American Journal of Veterinary Research, 177, 911-913.

Huffman, M. A., Gotoh, S., Turner, L. A., Hamai, M., \& Yoshida, K. (1997). Seasonal trends in intestinal nematode infection and medicinal plant use among chimpanzees in the Mahale Mountains, Tanzania. Primates, 38, 111-125.

Hugot, J. P. (1993). Rediscription of Enterobius anthropopitheci (Gedoelst, 1916) (Nematoda, Oxyurida), a parasite of Chimpanzees. Systematic Parasitology, 26, 201-207.

IUCN (2004). IUCN Red list of Threatened Species. http://www.redlist.org.

Jaskoski, B. J. (1960). Physalopteran infection in an orangutan. Journal of the American Veterinary Medical Association, 137, 307.

Jessee, M. T., Schilling, P. W., \& Stunkard, J. A. (1970). Identification of intestinal helminth eggs in old world primates. Laboratory Animal Care, 20, 83-87.

Kalema, G. (1995). Epidemiology of the intestinal parasite burden of mountain gorillas, Gorilla gorilla beringei, in Bwindi Impenetrable National Park, South West Uganda. Unpublished Report. Zebra Foundation for Veterinary Zoological Education, 19-34.

Kalema-Zikusoka, G., Kock, R. A., \& Macfie, E. J. (2002). Scabies in free-ranging mountain gorillas (Gorilla beringei beringei) in Bwindi Impenetrable National Park, Uganda. Veterinary Record, 150, $12-15$.

Kawabata, M., \& Nishida, T. (1991). A preliminary note on the intestinal parasites of wild chimpanzees in the Mahale Mountains, Tanzania. Primates, 32, 275-278. 
Kelly, A., Little, M. D., \& Voge, M. (1976). Stongyloides fulleborni-like infections in man in Papua New Guinea. American Journal of Tropcial Medicine and Hygiene, 25, 694-699.

Kilbourn, A. M., Karesh, W. B., Wolfe, N. D., Bosi, E. J., Cook, R. A., \& Andau, M. (2003). Health evaluation of free-ranging and semi-captive orangutans (Pongo pygmaeus pygmaeus) in Sabah, Malaysia. Journal of Wildlife Disease, 39, 73-83.

Kim, J. C. S., Abee, C. R., \& Wolf, R. H. (1978). Balantidiosis in a chimpanzee (Pan troglodytes). Laboratory Animals, 12, 231-233.

Landsoud-Soukate, J., Tutin, C. E. G., \& Fernandez, M. (1995). Intestinal parasites of sympatric gorillas and chimpanzees in the Lopé Reserve, Gabon. Annals Tropical Medicine and Parasitology, 89, 73-79.

Lee, R. V., Prowten, A. W., Anthone, S., Satchidanand, S. K., Fisher, J. E., \& Anthone, R. (1990). Typhlitis due to Balantidium coli in captive lowland gorillas. Reviews of Infectious Diseases, 12, 1052-1059.

Leeflang, P. D., \& Markham, R. J. (1986). Strongyloidiasis in orang-utans (Pongo pygmaeus) at Perth Zoo: An apparently successful eradication programme. International Zoo Year Book, 24/25, 256-260.

Levine, N. D. (1970). Protozoan parasites of nonhuman primates as zoonotic agents. Laboratory Animal Care, 20, 377-382.

Levine, N. D. (1973). Protozoan parasites of domestic animals and of manfs, (2nd ed.). Minneapolis, MN: Burgess.

Lilly, A. A., Mehlman, P. T., \& Doran, D. (2002). Intestinal parasites in gorillas, chimpanzees, and humans at Mondika research site, Dzanga-Ndoki National Park, Central African Republic. International Journal of Primatology, 23, 555-573.

McClure, H. M., Strozier, L. M., Keeling, M. E., \& Healy, G. R. (1973). Strongyloidosis in two infant orangutans. Journal of the American Veterinary Medical Association, 163, 629-632.

McGrew, W. C., Tutin, C. E. G., Collins, D. A., \& File, S. K. (1989). Intestinal parasites of sympatric Pan troglodytes and Papio spp. at two sites: Gombe (Tanzania) and Mt. Assirik (Senegal). American Journal of Primatology, 17, 147-155.

Mudakikwa, A. B., Cranfield, M. R., Sleeman, J. M., \& Eilenberger, U. (2001). Clinical medicine, preventive health care and research in the Virunga Volcanoes region. In M. M. Robbins, P. Sicotte, \& K. J. Stewart (Eds.), Mountain Gorillas: Three decades of research at Karisoke. Cambridge, UK: Cambridge University Press.

Mudakikwa, A. B., Sleeman, J., Foster, J. W., Meader, L. L., \& Patton, S. (1998). An indicator of human impact: Gastrointestinal parasites of mountain gorillas (Gorilla gorilla beringei) from the Virunga Volcanoes Region, Central Africa. In Proceedings of the Joint Meeting of the American Association of Zoo Veterinarians and the American Association of Wildlife Veterinarians, pp. 436-437.

Murray, S., Stem, C., Boudreau, B., \& Goodall, J. (2000). Intestinal parasites of baboons (Papio cynocephalus anubis) and chimpanzees (Pan troglodytes) in Gombe National Park. Journal of Zoo and Wildlife Medicine, 31, 176-178.

Nelson, E. C. (1934). Observations and experiments on conjugation of the Balantidium from the chimpanzee. American Journal of Hygiene, 20, 106-134.

Nizeyi, J. B., Mwebe, R., Nanteza, A., Cranfield, M. R., Kalema, G. R. N. N., \& Graczyk, T. K. (1999). Cryptosporidium $\mathrm{sp}$ and Giardia $\mathrm{sp}$ infections in mountain gorillas (Gorilla gorilla beringei) of the Bwindi Impenetrable National Park, Uganda. Journal of Parasitology, 85, 1084-1088.

Orihel, T. C. (1970). The helminth parasites of nonhuman primates and man. Laboratory Animal Care, 20, $395-401$.

Ott-Joslin, J. E. (1993). Zoonotic diseases of nonhuman primates. In M. E. Fowler (Ed.), Zoo and wild animal medicine: Current therapy, (3rd ed., pp. 358-373). Philadelphia: W. B. Saunders.

Patten, R. A. (1939). Amoebic dysentery in orang-utans (Simia Satyrus). Australian Veterinary Journal, $15,68-71$.

Pawlowski, Z. S. (1982). Ascarisiasis: Host-Pathogen biology. Reviews of Infectious Diseases, 4, 806814.

Polderman, A. M., \& Rijpstra, A. C. (1993). Medische parasitologie. Handleiding bij de laboratoriumdiagnostiek. 2e druk. Bohn Stafleu Van Loghum. Houten/Zaventem.

Rijksen, H. D. (1974). Orang-utan Conservation and Rehabilitation in Sumatra. Biological Conservation, 6, 20-25.

Rijksen, H. D. (1978). A Fieldstudy on Sumatran Orangutans (Pongo pygmaeus abelii Lesson 1827): Ecology, Behaviour and Conservation. H. Veenman \& B. V. Zonen. Wageningen.

Rijksen, H. D., \& Meijaard, E. (1999). Our vanishing relative. The status of wild Orangutans at the close of the twentieth century. Dordrecht: Kluwer Academic. 
Robertson, J. M. Y., \& Van Schaik, C. P. (2001). Causal factors underlying the dramatic decline of the Sumatran orang-utan. Oryx, 35, 26-38.

Rothman, J. M., Bowman, D. D., Eberhard, M. L., \& Pell, A. N. (2002). Intestinal parasites found in the research group of mountain gorillas in Bwindi Impenetrable National Park, Uganda-Preliminary results. Annals of the New York Academy of Sciences, 969, 346-349.

Schlegel, J., \& Müller, S. (1839-1844). Bijdragen tot de Natuurlijke Historie van de Orang-oetan (Simia satyrus). Zoologie, 2, 1-28.

Schmidt, R. E., \& Prine, J. R. (1970). Severe enterobiasis in a chimpanzee. Pathologia Veterinaria, 7, 56-59.

Singleton, I., \& Van Schaik, C. P. (2001). Orangutan home range size and its determinants in a Sumatran swamp forest. International Journal of Primatology, 22, 877-911.

Singleton, I., Wich, S., Husson, S., Stephens, S., Utami Atmoko, S., Leighton, M., et al. (2004). Orangutan population and habitat viability assessment: Final report. Apple Valley, MN: IUCN/SSC Conservation Breeding Specialist Group.

Sleeman, J. M., Meader, L. L., Mudakikwa, A. B., Foster, J. W., \& Patton, S. (2000). Gastrointestinal parasites of mountain gorillas (Gorilla gorilla beringei) in the Parc National des Volcans, Rwanda. Journal of Zoo and Wildlife Medicine, 31, 322-328.

Smith, H. V., Paton, C. A., Girdwood, R. W. A., \& Mtambo, M. M. A. (1996). Cyclospora in non-human primates in Gombe, Tanzania. Veterinary Record, 138, 528.

Thienpont, D., Rochette, F., \& Van Parijs, O. F. J. (1979). Diagnose van Verminose door Koprologisch Onderzoek. Beerse, Belgium: Janssen Research Foundation.

Uemura, E., Houser, W. D., \& Cupp, C. J. (1979). Strongyloidiasis in an infant orangutan (Pongo pygmaeus). Journal of Medical Primatology, 8, 282-288.

Van Noordwijk, M. A., \& Van Schaik, C. P. (2005). Development of ecological competence in Sumatran orangutans. American Journal of Physical Anthropology, 127, 79-94.

Van Schaik, C. P., Monk, K. A., \& Robertson, J. M. Y. (2001). Dramatic decline in orang-utan numbers in the Leuser Ecosystem, Northern Sumatra. Oryx, 35, 14-25.

Van Waerebeke, D., Chabaud, A. G., \& Collet, J. Y. (1988). New Atractid nematodes parasite of chimpanzee and gorilla in Gaboon. Annales de Parasitologie Humaine et Comparee, 63, 37-47.

Warren, K. S. (2001). Orangutan Conservation-Epidemiological Aspects of Health Management and Population Genetics. Ph.D. thesis, Murdoch University.

Wich, S. A., Singleton, I., Utami-Atmoko, S. S., Geurts, M. L., Rijksen, H. D., \& Van Schaik, C. P. (2003). The status of the Sumatran orang-utan Pongo abelli: An update. Oryx, 37, 49-54.

Wich, S. A., Utami-Atmoko, S. S., Mitra Setia, T., Rijksen, H. R., Schürmann, C., Van Hooff, J. A. R. A. M., et al. (2004). Life history of wild Sumatran orangutans (Pongo abelii). Journal of Human Evolution, 47, 385-398.

Woodford, M. H., Butynski, T. M., \& Karesh, W. B. (2002). Habituating the great apes: The disease risk. Oryx, 36, 153-160.

Wrangham, R. W. (1995). Relationship of chimpanzee leaf-swallowing to a tapeworm infection. American Journal of Primatology, 37, 297-303. 